University of Nebraska - Lincoln

DigitalCommons@University of Nebraska - Lincoln

Publications from USDA-ARS / UNL Faculty

U.S. Department of Agriculture: Agricultural

Research Service, Lincoln, Nebraska

1957

RECENT ADVANCES IN VETERINARY ENTOMOLOGY1

A.W. LINDQUIST

United States Department of Agriculture

E. F. KNIPLING

United States Department of Agriculture

Follow this and additional works at: https://digitalcommons.unl.edu/usdaarsfacpub

LINDQUIST, A.W. and KNIPLING, E. F., "RECENT ADVANCES IN VETERINARY ENTOMOLOGY1" (1957). Publications from USDA-ARS / UNL Faculty. 2221.

https://digitalcommons.unl.edu/usdaarsfacpub/2221

This Article is brought to you for free and open access by the U.S. Department of Agriculture: Agricultural Research Service, Lincoln, Nebraska at DigitalCommons@University of Nebraska - Lincoln. It has been accepted for inclusion in Publications from USDA-ARS / UNL Faculty by an authorized administrator of DigitalCommons@University of Nebraska - Lincoln. 


\title{
RECENT ADVANCES IN VETERINARY ENTOMOLOGY ${ }^{1}$
}

\author{
By A. W. LINDQUist and E. F. KNIPLING \\ Entomology Research Branch, Agricultural Research Service, United States \\ Department of Agriculture, Beltsville, Maryland
}

The advances during the last 15 years in our knowledge of the biology and control of arthropod pests of livestock and vectors of animal disease agents exceed those made in any similar period in past history. Before 1942 we relied mainly on rotenone, pyrethrum, the thiocyanates, and the arsenicals for control of lice, ticks, mites, biting flies, and cattle grubs. While effective against some pests under certain conditions, these materials were not practical for wide-scale use and did not meet the public demand for better insecticides. Today we have highly effective and low-cost insecticides such as DDT, lindane, TDE, toxaphene, methoxychlor, chlordane, and synergized pyrethrum for control of livestock insects. Their use has saved the livestock grower many millions of dollars annually and has benefited the consumer by making more and better animal products available.

Of almost equal importance to the development of the new insecticides are the contributions made to our knowledge of the biology and habits of several livestock insects and their transmission of agents of animal diseases. Many new ideas and approaches to studies on insect biology and control have been developed during the last few years. A good example of this is the unique method for the control of screw-worms by release of sterilized male flies over an area. The sterile males mate with the native females, but the eggs are infertile and thus reduce the numbers of screw-worms. Another example of new trends is the promising research with insecticides that can be given internally to livestock for destruction of external pests. These studies will be discussed in detail in the following pages.

Although great progress has been made in the use of insecticides, two disturbing factors have arisen to cause worry as to the future efficiency of chemical means of control. The first is the increasing and widespread development of resistance of insects to insecticides, particularly to the chlorinated hydrocarbons. House flies have developed such a high degree of resistance to DDT and related materials that satisfactory control is impossible in most areas. Organic phosphorus insecticides have so far performed in a creditable manner in controlling house flies, but there are indications that these chemicals may eventually fail. As yet no reports on resistance of horn flies, horse flies, deer flies, stable flies, sheep keds, or lice of livestock have appeared.

Ticks have become highly resistant to DDT, BHC, and toxaphene and other chemicals in certain areas in South Africa and Australia [Whitnall

1 The survey of literature pertaining to this review was completed in April, 1956. 
et al. (1); Fiedler (2); Hitchcock (3)]. No doubt, other livestock insects will become resistant to insecticides, and it is readily understood that this stimulates extensive research to develop new materials. For detailed information on the genetic and biochemical aspects of resistance of arthropods to insecticides the reader is referred to an excellent review by Hoskins \& Gordon (4).

The other disturbing influence is the finding that most of the chlorinated hydrocarbon insecticides applied to livestock are absorbed by the skin and stored in the fat, meat, or milk. A vast amount of research has been done to determine the amounts of various insecticides thus stored. In the United States the amounts of pesticides that are tolerated in edible food are regulated by law. The passage in 1954 of the Miller amendment to the Food, Drug and Cosmetic Act has made it necessary to intensify research on insecticide residues in animal products.

In the last few years several hundred papers have appeared that in one way or another deal directly with or relate to insects of veterinary importance. This large number is understandable when one recognizes that many hundreds, perhaps thousands, of species of insects attack animals. Many of the papers are on the taxonomy of single species or groups of genera and species. For the purposes of this paper it is not practical to refer to each of the papers. Furthermore, numerous species attack man as well as animals and reports on the taxonomy, biology, and control may refer primarily to the insect as it relates to man and may therefore not be directly applicable to the present scope of this paper.

It is the purpose of the writers to review numerous publications and to discuss important and significant trends in research on insects affecting animals. Complete coverage is not contemplated and many papers reporting excellent research will of necessity be omitted. Because of Fuller's (5) review of work on ticks and mites in relation to animals, no reference will be made to these important arthropods. Neither will house flies as livestock pests be discussed, since Lindsay \& Scudder (6) reviewed the role of these flies in relation to disease of both man and animals. It is believed the reader will understand that the scope of veterinary entomology is indeed enormous and that there is increasing interest and a growing number of research papers.

\section{Biting Flies}

Biting or bloodsucking flies of several families, numbering hundreds of species, are the most important livestock insect pests. Some species of biting flies are found wherever man and animals live.

Glossina.-Biting flies of the genus Glossina (tsetse flies) are restricted to Africa south of the Tropic of Cancer. These flies, infesting about $4 \frac{1}{2}$ million square miles of land, are enemies of both man and animals, and have been a serious obstacle to the development of tropical Africa. The livestock industry has fared badly in these areas, since the trypanosome causing nagana is transmitted by these insects. At least 21 species of Glossina may feed on cattle and are capable of transmitting the agent of this disease. 
Numerous papers on various aspects of the biology, control, and disease transmission of tsetse flies have appeared during the past 25 years.

Research on the control of tsetse flies has been directed along many different lines of attack, and against all stages of the pest. Control of pupae in breeding places by means of parasites, mechanical devices, and insecticides has been studied. Fly traps, screens, adhesive surfaces, reducing or expelling game animals (thus depriving the flies of food supply), clearing of thickets and/or modification of cover (according to the habits of the particular species), and introducing appropriate agricultural practices as well as application of insecticides directly on cattle and against the adult fly on an area basis have also been studied.

Buxton (7) has critically reviewed most of the literature in his comprehensive book on the natural history of tsetse flies. This book brings together a vast amount of knowledge and coordinates laboratory and field experiments and observations. It includes discussions of the anatomy, taxonomy, distribution, physiology, food, and relationships to the environment as well as a long chapter on control. The last two chapters deal with the importance of entomology to the epidemiology of the human and animal trypanosomiasis. Twenty-seven pages of references up to 1952 are listed, including numerous mimeographed papers and reports that are not readily available.

Another excellent review on trypanosomiasis and control of tsetse flies by chemical means in Zululand is by du Toit (8). This 70-page treatise deals with the distribution of nagana and its importance to the livestock industry, the bionomics of Glossina species in Zululand, and survey methods. The report on application of DDT and BHC with aerial sprays and aerosols and hand-dusting equipment for adult control is especially good. The methods of chemical control are well illustrated, and there are maps on distribution of various species of adults and of the concentrated larval breeding beds.

A detailed entomological study of Glossina palpalis (Robineau-Desvoidy) in northern Nigeria by Nash \& Page (9) yielded much information on populations of the fly, its flight range, suitable macro- and micro-climates during dry and hot seasons, and longevity. Evidence derived from recovery of marked specimens indicates that females live up to 60 days. The authors estimate that wild female flies will live from six to fifteen weeks and the males from four to eight weeks according to the-season. Jackson (10) has discussed marking adults of Glossina for release and subsequent recapture in population studies. A simultaneous census of two species of Glossina and animal hosts made along the Kenya shore of Lake Victoria by Glasgow \& Wilson (11) indicated that an average of 291 flies fed daily on each animal, eausing it to lose $17.5 \mathrm{gm}$. of blood per day.

Efficient methods of rearing insects in the laboratory are important in entomological work. Nash (12) studied fertilization of $G$. palpalis in the laboratory in order to rear large numbers at reasonable cost. It was found that females two days or six to ten days old were difficult to fertilize. Fertilization was greatest among three-day-old females. Males seven to eight 
days old were more virile and produced a higher per cent of fertilization than younger or older groups. In large-scale breeding it was most efficient to place three-day-old females with twice as many males seven days of age.

Glover et al. (13) reported on the extermination of Glossina morsitans Westwood at Abercorn in northern Rhodesia. Fire exclusion with the object of allowing woody vegetation to thicken so as to make it unfavorable for the flies was begun in 1936 and continued to 1946. Catches of flies were reduced by one-third. In addition, shallow valleys forming the headwater of streams and harboring concentrations of flies were cleared of trees. The flies were greatly reduced, and cattle can now be kept free of trypanosomes in the Abercorn area.

The effect of DDT and BHC sprays on the parasites of tsetse flies in a Zululand fly-eradication campaign was studied by Fiedler et al. (14). At first it appeared that the spray campaign did not severely affect the parasites, but later it was found that both insecticides reduced the parasites before tsetse flies were eliminated. It was concluded by these authors that it is unwise to attempt eradication unless rapid and complete elimination of the fly can be achieved by insecticidal or other equally effective means.

Burnett (15) reported on an experiment in Tanganyika Territory designed to eliminate two species of Glossina by means of bait cattle sprayed with DDT. It is estimated the ratio of sprayed cattle to large game was no more than three to one. G. moristans was reduced by 99.5 per cent and Glossina swynnertoni Austen by $\mathbf{9 2 . 5}$ per cent. It was surmised that this method might check the disease in an area.

Hocking et al. $(16,17,18)$ describes airplane spray (aerosol) experiments over large areas in the central province of Tanganyika against adults of Glossina. In the first experiment seven applications of 0.25 pound of DDT per acre over a $3 \frac{1}{2}$-month period reduced adult populations 95 per cent or better. In the second experiment BHC was used. It was less successful than the first one because of a variety of factors, but probably the rainy season and full leaf forest canopy reduced the spray effectiveness. In the third experiment, conducted in an isolated area where infiltration of flies was unlikely, seven applications of DDT at 0.25 pound per acre at fortnightly intervals reduced the flies almost to extinction.

Tabanids.-Tabanids are among the most important bloodsucking insects affecting man and animals. They not only are severe pests but transmit several disease agents. The many hundreds of species are receiving much attention on a world-wide basis from a taxonomic viewpoint. The need for organizing the mass of information on many species, and preparing keys for their identification, has stimulated capable workers to attack the problem in several countries.

Oldroyd's (19) monograph on the horse flies of the Ethiopian region is an outstanding contribution to the knowledge of classification of this group. Besides the systematic study the volume contains information on the habits, 
early stages, morphology, and transmission of disease. The 31 maps show distribution of species groups for 147 species.

Two recent publications by Philip $(20,21)$ add to our knowledge of North American Tabanidae. The earlier work contains notes and keys to the genera and species of Pangoniinae exclusive of Chrysops. It provides keys for the subfamily Pagoniinae in the entire continent which is far better than arbitrarily separating the tabanid fauna north of Mexico from that of the Mexican, Central American, and Caribbean areas. The later paper presents similar notes and keys to the genus Chrysops.

The classification and distribution of Tabanidae in Australia has been studied by Mackerras $(22,23)$. His papers represent a thorough systematic overhauling of the groups, including study of the genitalia together with other characters.

Basu et al. (24) published on the distribution of tabanid flies in India and their relationship to surra [Trypanosoma evansi (Steel)], a disease highly fatal to equines, camels, bovines, and dogs. They list 75 species known to occur not only in India, but in Pakistan, Ceylon, Burma, and the PersiaBaluchistan-Afghanistan area. Distribution maps of most of the species are given. Seven of the species transmit surra. Tabanus rubidus Wiedemann is undoubtedly the principal vector in India.

The effect of light on the biting activity of Chrysops silacea Austen in the forest at Kumba, British Cameroons, was studied briefly by Crewe (25). He concluded that there was no close correlation between biting activity and measured light intensity.

Fairchild (26) studied the arboreal habits of tabanids in Panama and found that several species preferred the upper forest canopy to ground level. Several groups of these flies seem to prefer this upper habitat. This is not surprising in view of the many mammals living in a tropical arboreal element. Lumsden (27) presented data on the biting habits of several groups of insects, including tabanids, in the forest canopy in Uganda. Duke (28) studied the biting habits of $C$. silacea by trapping them at various levels above the ground. Most of the flies were caught between 11 a.m. and 3 p.m. at heights of 28 and $92 \mathrm{ft}$.

Information on the life history is available for comparatively few species of the tabanids. The immature stages develop slowly, the time required to attain maturity ranged from a few months to over two years. Jones (29) summarizes a large amount of research in Florida on the distribution, seasonal occurrence, abundance, life history, larval habits, and natural enemies of tabanids. Specimens reared to maturity from field collected larvae and eggs showed the various species had an incubation period of four to six days, larval period of 220 to 807 days, and pupal period of five to fourteen days. Larval habitats were usually in swamps and around lakes, ponds, and streams, but a few larvae were found in rather dry places. Parasites and predators of all four stages of tabanids were recorded. Preliminary work on 
the biology and distribution of 30 species of tabanids in Mississippi was reported by Lewis \& Jones (30). Blickle (31) lists tabanids from New Hampshire, and Fairchild (32) lists those from Connecticut. Knutson et al. (33) list 37 species from New England.

Research on control of tabanids has consisted mainly in the use of insecticides on an area basis to destroy adults and of sprays to livestock to protect them against attack by the flies. Neither of these two methods have been effective or practical. Likewise, insecticides for control of larvae have not shown much promise, because the larvae are usually distributed over such large areas and embedded in soil or under water where insecticides do not reach them.

Brown \& Morrison (34) conducted large-scale aerial spray tests in Canada to control adult tabanids. Lindane at 0.5 pound per acre eliminated Tabanus and Chrysops for two days in open situations, but in wooded areas caused only an 82 per cent reduction. A dosage of 0.25 pound per acre gave poor results even in open forest. DDT at dosages up to two pounds per acre gave temporary reductions of 53 to 100 per cent, but there was no evidence that the residue on vegetation was effective. Dieldrin at one pound per acre gave poor results. This work is of interest because of the unique methods of evaluating results. The population was assessed from landing rate on small tents made of black cotton cloth. Further checks were made by tethering flies to branches in the sprayed area by means of yellow nylon thread tied around the abdomens. One must conclude from this and other aerial spray work that control of tabanids on an area basis is difficult and expensive.

Roth (35) evaluated 16 insecticides against Chrysops discalis Williston by topical applications of measured dosages on collected flies. Lindane, the most effective insecticide, gave 100 per cent kill at $0.05 \mu \mathrm{gm}$. per fly, and the LD-50 was approximately $0.035 \mu \mathrm{gm}$., which was about $\frac{1}{13}$ that for toxaphene. Surprisingly enough, EPN, malathion, Diazinon, and other organic phosphorus compounds were less effective than most of the chlorinated hydrocarbons.

Roth et al. (36) evaluated 258 synthetic organic compounds as repellents in the laboratory using mice as the host animals and starved $C$. discalis as the test insects. Only a few compounds showed promise as long-lasting repellents. Tests in the field with five of the best materials applied on calves against mixed populations of tabanids showed protection of $2 \mathrm{hr}$. to $3 \frac{1}{2}$ days. Pyrethrum and allethrin sprays did not protect animals for more than three days even when used at high concentrations. Field tests with sprays applied to livestock to protect them against tabanids are reported by Goodwin et al. (37), and Bruce \& Decker $(38,39)$. They showed pyrethrum preparations were practical and effective against tabanids in the midwestern and eastern United States.

A valuable contribution to the application of insecticides on cattle for the control of biting flies was made by Bruce (40), when he designed a walkthrough treadle-sprayer which permitted the cattle to treat themselves 
when going to the barn or to water. A mist of insecticide, usually a pyrethrum concentrate, is sprayed on the animals.

Outbreaks of vesicular stomatitis, a disease of livestock, particularly of hogs, seem to be associated with the eating of raw garbage. This disease is known to have spread rapidly from a center of infection making mysterious jumps of great distances where roads and other means of travel between farms are lacking. This has suggested that the virus may be insect borne. In studies on the laboratory transmission of vesicular stomatitis Ferris et al. (41) developed a method of using embryonated chicken eggs for use as both the infective and susceptible hosts. Twenty-eight species of biting Diptera were tested. Six species of Tabanus, three of Chrysops as well as some mosquitoes and the stable fly, were able to transmit the virus under laboratory experimental conditions. The transfer of the virus of vesicular stomatitis appeared to be mechanical, i.e., carried on the mouth parts of the insects. In field tests when horse flies, stable flies, and mosquitoes were exposed to the virus and allowed to bite two cows, transmission could not be demonstrated.

It seems appropriate to call attention to the valuable paper of Day $\&$ Bennetts (42) on specificity in arthropod vectors of plant and animal viruses. There is increasing evidence that any pathogen can be transmitted by more than one species of vector. The occurrence and significance of specificity in insects are discussed. The data on pathogens of medical and veterinary importance are summarized in $\mathbf{4 8}$ pages which includes 9 rickettsiae and 28 animal viruses that may be transmitted by insects. These records list species of insects that have been proved in laboratory and field experiments to be vectors and the species that have failed to transmit the disease. In addition information is given on the viability of the virus, multiplication within the vector, and type of transmission. This is a valuable compilation and review on a subject important to veterinary entomologists.

Stable fly. - The stable fly [Stomoxys calcitrans (Linnaeus)] is a vicious bloodsucking pest of livestock and is widely distributed. Very little research information has appeared on the biology, habits, and breeding sites of this insect in recent years. Champlain et al. (43) and McGregor \& Dreiss (44) provide useful new information on rearing the insect in the laboratory since availability of large numbers of flies for insecticide testing and other purposes is important in research.

Effective sprays to protect animals against stable flies have not yet been found that are practical for use on range animals. Pyrethrum and allethrin fortified with synergists are the best materials, but they do not afford protection for more than a few days, when used at maximum practical strengths. Their short and erratic performance precludes general use on range cattle. Moore et al. $(45)$ and Bruce \& Decker $(38,39)$ have studied formulations and give results of practical field tests. In research on residual spraying of barns on various types of farms Dahm \& Raun (46) evaluated several organic phosphorus insecticides. Diazinon appeared to be the most effective. 
Horn fly.-Before the advent of DDT there was no practical means of controlling the horn fly [Siphona irritans (Linnaeus)] on range cattle. Control of this pest on dairy cows or small herds of beef cattle could be accomplished only by daily treatment with mist sprays containing pyrethrum or the organic thiocyanates. It is now our easiest livestock insect to suppress on beef cattle, for sprays of DDT, TDE, toxaphene, or methoxychlor are very effective for three to six weeks. Methoxychlor is the only chlorinated hydrocarbon insecticide recommended for use on dairy animals because the other materials effective for horn-fly control result in excessive residues in the milk. Many experiments have been conducted comparing the effectiveness of different insecticides against the horn fly. State and federal leaflets give recommendations on approved materials and methods of application on both beef and dairy cattle.

Studies on the increase of milk yields when cows were protected against horn flies, stable flies, and horse flies were conducted by Bruce \& Decker $(47,38)$. They showed that herds treated with DDT for protection against horn flies produced significantly more milk than did untreated herds. Herds protected against horse flies with frequent applications of synergized pyrethrum showed a highly significant increase in butterfat production. Laake (48) showed that sprayed cattle in about two months gained about 50 pounds more than unsprayed cattle.

An important contribution in simplifying methods of application of insecticides was the development by Rogoff (49) and Rogoff \& Moxon (50) of rubbing devices for horn-fly control. These devices, usually consisting of insecticide-treated burlap sacks wrapped around a chain or cable suspended between two posts, have given excellent control after the cattle learned to rub against them. Further work by Lindquist \& Hoffman (51) and others confirmed the usefulness of this method of horn-fly control.

Culicoides.-Culicoides, family Heleidae, have become of increasing interest to entomologists and others during the last few years. The taxonomy of the group is being overhauled by several workers. A paper by Foote \& Pratt (52) on the Culicoides of the eastern United States contains keys to numerous species, with notes on their distribution and biology. Khalaf (53) writing on the speciation of the genus treats the group from a world-wide basis. Other papers by Vargas \& Wirth (54), Vargas (55), Kettle \& Lawson (56) Forattini (57), Ortiz \& Leon (58), Wirth (59), and Williams (60) describe new species or groups of species.

The biology and ecology of the Culicoides have not been intensively studied, but recent papers by Blanton et al. (61), Woke (62), and Okada (63) present information on several species. Observations on the swarming flight and mating of Culicoides are reported by Downes (64), and also information on the biology of two species in Great Britain.

A newly discovered disease of sheep in the United States, at first named "sore muzzle" was reported by Hardy \& Price (65). This disease appeared to be similar to one known as "bluetongue" in South Africa. During a visit 
to this country R. Alexander, Director of Veterinary Services in the Union of South Africa, and an authority on the disease, confirmed the fact that the American and African bluetongue disease of sheep are similar. Culicoides were known to be vectors of the disease in Africa. Price \& Hardy (66) isolated the virus from sheep in Texas and performed experiments that suggested Culicoides variipennis (Coquillett) was a vector. Their experiments were not conclusive, and positive transmission information will be difficult to obtain until Culicoides can be readily reared in the laboratory. Very likely $C$. variipennis is a vector of the agent of bluetongue disease in this country. but other species may also be involved. Research is now under way to determine the distribution and larval habitats, and to develop laboratory methods of rearing, and methods of control of $C$. variipennis and related species.

An allergic dermatitis of the horse was shown by Riek (67) to be caused by hypersensitivity to bites of Culicoides robertsi Lee and Reye. This hypersensitivity was associated with an increase in the histamine concentration in the blood during the summer months and reached its maximum during the late, afternoon and early evening, when the Culicoides were most active. A rise in blood histamine was also observed in susceptible horses for a short period after the injection of an antigen prepared from this fly.

Most of the research on the control of Culicoides has been in relation to their attack on man. Treating screens with insecticides and repellents has prevented entry into buildings. Labrecque \& Goulding (68) found that granulated dieldrin at 1.25 pounds and $\mathrm{BHC}$ at 2 pounds of gamma isomer per acre reduced larval breeding of Culicoides furens (Poey) in Florida saltmarshes for 12 to 24 weeks, respectively. Previously sprays applied from the air failed to give satisfactory larval control because the dense cover prevented the penetration of most of the material to the mud flats.

Black flies.-Most species of black flies (Simuliidae) are vicious pests of man and animals, and in addition they are carriers of several disease agents. Taxonomic studies have not been numerous during the last two years, but Bentinck (69) has reported on the black flies of Japan and Korea, giving taxonomic information on the several species as well as notes on the geographical distribution, ecological preferences and biting habits. The Japanese black flies had received relatively little study prior to this publication. The illustrations showing taxonomic characters are excellent. Freeman \& de Meillon (70) published a large treatise on the simuliids of the Ethiopian region. A well illustrated treatise on the black flies of New York State with keys to the larvae, pupae, and adult females was presented by Stone $\&$ Jamnback (71).

Sommerman et al. (72) published a study of the black flies of Alaska, giving special attention to larval habitats and the life histories of approximately 35 species. Only five or six of these black flies are known to feed on humans in Alaska. Sailer (73) gives similar information, stating that surprisingly few biting records have been obtained in several years' observations. Al- 
though biting records on man are scarce in Alaska, there is no dearth of information on the vicious biting habits of these flies in other areas. Bierer (74) described severe outbreaks of black flies in the United States when livestock were tortured and even killed by these pests. Curtis (75) reports on cattle-infesting black flies closely related to Simulium arcticum Mallock in British Columbia, which cause serious loss of weight in beef cattle by their vicious biting. He also gives some interesting life history information on this species. Edgar (76) reported that an outbreak of Simulium meridionals Riley caused egg production of Leghorn hens to drop sharply from 70 to 20 per cent within eight days. After the outbreak the hens recovered and egg production returned to normal.

A comprehensive volume on black flies and their role as transmitters of disease agents in Guatemala by Dalmat (77) presented detailed information on breeding habits, distribution, life history and taxonomy of black flies as well as their relation to transmission of onchocerciasis, an important disease of man in South and Central America and parts of Africa. The book is well illustrated with photographs, maps, and line drawings.

Hocking \& Pickering (78) reported on the bionomics of some species of Simuliidae in northern Manitoba. Information is presented on the larval and pupal habits, mating, feeding, oviposition, and parasites and predators of several species. Methods of rearing field-collected larvae in the laboratory are described.

Black-fly breeding in irrigation canals and water drops has been observed by entomologists over a number of years, but little on this subject has been published. Edmunds (79) made a survey in an irrigated area in western Nebraska after farmers had complained of small flies bothering their livestock. He found black-fly pupae and larvae in small numbers along the edges of the main canals, especially where the water was moving swiftly, and in large numbers in the concrete drop structures. Of 206 drop structures examined, black flies were found in 93 per cent of them. Collections were identified as Simulium vittatum Zettersted t and Simulium griseum Coquillett. With the enormous increase in irrigation in the Western States it is expected that black flies as well as mosquitoes will increase and cause trouble to livestock growers.

Black flies transmit a leucocytozoon disease of poultry. This disease has been reported from several states but is particularly prevalent in Jasper County, South Carolina. Jones \& Richey (80) reported on the biology of black flies and their relationship to the disease. Ecological information was obtained on eight species breeding in the slow-moving, meandering streams but only two of them, Simulium slossonae Dyar and Shannon and Simulium congareenarum (Dyar and Shannon), were found feeding on turkeys. Reports on the causative parasite and transmission to turkeys have been published by Simms (81), Richey \& Ware (82), and Newberne (83).

Control of black-fly larvae has been of considerable interest since Fairchild \& Barreda (84) demonstrated that the application of 0.1 to 0.2 p.p.m. 
of DDT would rid a stream of larvae for a distance of several miles. This method of control has been tested by many investigators, including Gjullin et al. (85), Hocking (86), Vargas (87), and Lea \& Dalmat (88), and it proved to be outstanding in reducing the black flies. The effectiveness of controlling black-fly larvae up to several miles by dripping DDT into a stream at low concentrations for periods of 10 to $60 \mathrm{~min}$. is phenomenal.

An experiment in eradication of Simulium neavei Roubaud, the vector of onchocerciasis in the Kodera district of Kenya, has been reported by Garnham (89). In 1946 DDT was applied to all streams in the district, and annual surveys since then have failed to yield larvae or adults. Although the incidence of microfilariae in children has been reduced, the disease has not been eradicated. Hocking \& Richards (90) and Lea \& Dalmat (91) have treated streams in large areas and demonstrated great reductions of black flies. Infiltration of flies from untreated areas hinders their complete elimination.

Although 0.1 to 0.3 p.p.m. of DDT has been effective in various field tests conducted by different workers, low concentrations were not sufficient to kill larvae in laboratory tests. Apparently Lea \& Dalmat (92) were the first to report low kill of larvae. They found that exposure to 10 p.p.m. of DDT for 30 min. would not always cause 100 per cent mortality. Apparently the effectiveness in the field is attributable to the fact that DDT causes the larvae to detach from rocks and vegetation, and they are swept downstream. They are then subjected to predation by fish and other animals. Observations such as these emphasize the importance of understanding the biology of an insect and the mode of action of insecticides in evaluating their effectiveness in both laboratory and field tests.

Jamnback \& Collins (93) published an informative and well illustrated volume on the control of black flies in New York. Data are presented on the effectiveness against adults of insecticides applied by ground fogging machines, conventional aircraft, and helicopters. Results of tests against larvae and the effects of insecticides on fish, both directly and indirectly, through destruction of their food are given.

\section{Bot Flies}

Very little research on the control of the human bot fly, Dermatobia hominis (Linnaeus, Jr.), an important pest of cattle in Central and South America, was done prior to 1948. Dips containing arsenious oxide have been used extensively for their control in Central and South America for many years. Laake (94) reported on experiments conducted in 1948 in Brazil with toxaphene sprays on cattle. This insecticide reduced the number of larvae infesting cattle. The grub reduction was probably a result of the destruction of biting flies and mosquitoes that carry the Dermatobia eggs which leads to infestation in livestock; however, no data are available to show that the treatment does not affect the hatching larvae.

Neel (95) reported on the use in Costa Rica of sprays containing 0.5 
per cent of toxaphene, 0.15 per cent of aldrin, 0.5 per cent of DDT plus 0.03 per cent of gamma BHC. Applications every two weeks for approximately four months significantly reduced the infestations of larvae under the skin. There appeared to be no significant difference between the insecticides used. Adams et al. (96) tested 0.5 per cent toxaphene emulsions on Nicaraguan cattle for Dermatobia larvae control. The infestations were reduced to about 3 per cent of the controls after six or seven biweekly sprayings.

Garr (97) reported on a new means of controlling the sheep bot fly (Oestrus ovis Linnaeus). Of many substances tested, the ether extract of male fern (Dryopteris filix-mas) gave best results. The extract was emulsified with an equal amount of alcoholic soap solution in water in which 0.2 per cent of anhydrous sodium carbonate had been dissolved. First-instar larvae dipped in the solution became paralyzed. Infested sheep sprayed in the nostrils with about $10 \mathrm{ml}$. of the solution soon discharged from one to 200 paralyzed first-instar larvae per animal.

Breev \& Karazeeva (98) reporting on Oedemagena tarandi (Linnaeus) infesting reindeer in the northwestern part of the Soviet Union, confirmed that the larvae spend 10 months in the body of the host. The warbles usually appear between the fifth and fifteenth of October, and it is important to slaughter the animals before the larvae appear so as to have hides without holes in them. Oviposition and subsequent appearance of grubs under the skin are dependent on temperature. The best time to squeeze out the larvae is in May and early June. Healthy and well-nourished animals were reported least infested.

Experiments to find ways of protecting reindeer from attack by 0 . tarandi by destroying the females during their oviposition period have been reported by Breev \& Savel'ev (99). Driving animals through a cloud of finely dispersed DDT or BHC resulted in a sharp decrease of adults and subsequent larval infestations. A method of spraying an entire herd in the open was devised which consisted of attaching spray nozzles to a long pole and drifting the insecticide over the animals. In this way two to three thousand reindeer could be treated in less than two hours.

The development of new sprays for use on the backs of cattle to destroy grubs, Hypoderma lineatum (De Villiers) and bovis (Linnaeus), has not progressed very fast for several years. Smith \& Richards (100) reported preliminary results with several organic phosphorus insecticides applied as washes. Bayer L 13/59, 21/199, and Diazinon at 0.5 per cent destroyed 84 to 92 per cent of lineatum, but malathion, EPN, and dieldrin were ineffective at the concentrations used. Similar tests conducted in Oregon by Roth \& Eddy (101) indicated that Bayer 21/199 (3-chloro-4-methylumbelliferone0,0-diethyl thiophosphate) as a wash was effective against lineatum and as a spray was more effective than rotenone against boois.

Kühl (102) reports on spraying cattle with DDT and gamma BHC plus chlordane at three-week intervals during the fly season, but neither spray reduced the grub infestations significantly. Raun (103) tested pyrethrum 
sprays during the fly season to prevent oviposition by heel flies. An automatic treadle-type sprayer was used to treat the cattle daily. Based on grub-incidence records the spray prevented some oviposition by lineatum but not by bovis.

An important new approach to possible control of bovis by interrupting the larval developmental period in the vertebral canal and tissues was proposed by Lienert \& Thorsell (104). The migration of larvae of this species in the host is thought to be a mechanical process or a combination of boring and production of a toxin that dissolves muscle tissue and skin. The authors suggested that enzymes are involved in the forward progression of the larvae and that inhibition of the enzymes might destroy the larvae. Experiments showed that autolysates from larvae collected in the spinal canal exert a splitting effect on the collagens only. Inhibition of the collagencollagenase system could therefore prevent larvae from developing.

Progress in the control of cattle grubs through the use of systemic insecticides is discussed under Systemic Insecticides.

\section{BLOW Flies}

Blow fly strike has been a serious problem to the sheep industry in Australia for many years. Early literature implicated Phaenicia sericata (Meigen) as the species chiefly responsible. In the mid-thirties evidence began to accumulate showing that Phaenicia cuprina (Wiedeman) was the most important sheep blow fly in Australia and that $P$. sericata was not of economic importance. These two species differed morphologically and in distribution and habits. Waterhouse \& Paramonov (105) have described characters whereby larvae and adults of both species may be recognized. They reported on hybridization experiments that indicated there was great difficulty in obtaining successful matings. The authors presented data showing that 58.3 per cent of naturally infected sheep harbored $P$. cuprina and no other species. This species is of little economic importance in the United States, but $P$. sericata oviposits at times on soiled or damp wool and causes losses among sheep.

In Australia P. cuprina oviposits on the body of sheep carrying 6 to 12 months' wool and on the crutch. The Mules operation combined with correct docking and tail operations has reduced blow fly strike on the crutch. Waterhouse \& Scott (106) found that 2 per cent DDT sprayed on the backs of sheep was the best insecticide tested and in insectary tests protected sheep against oviposition by $P$. cuprina for 6 to 8 weeks. Crude BHC preparations containing 0.5 per cent of the gamma isomer gave valuable protection. Chlordane and toxaphene gave only fair results. In similar studies Riches \& O'Sullivan (107) reported that sheep were protected from 6 to 7 weeks with 0.01 per cent gamma BHC, 7 to 8 weeks with 0.01 per cent aldrin and dieldrin, 13 to 14 weeks with 0.25 per cent gamma $\mathrm{BHC}$, and 16 to 18 weeks with 0.25 per cent aldrin and dieldrin. Best results were obtained when the spray was driven into the wool with a straight stream. 


\section{LICE}

Lice on livestock are important to the stockman, since he must control them in order to insure proper weight gains. Peterson et al. (108) found that heavy infestations on cattle produced severe anemia, at times reducing the red-blood cells to such an extent that it was necessary to destroy the lice to prevent the host from dying. When the condition of the animals under study became critical as a result of loss of blood, it was not materially altered by additional feed or improved care.

Satisfactory control of lice on cattle, sheep, goats, and hogs with insecticides has been worked out, and most of the literature on the subject is five or more years old. Readers are referred to Knipling (109) and United States Department of Agriculture leaflets $(110,111)$ for details of recommended control procedures and insecticides.

In the development of lower cost methods of treatment for control of lice on cattle, the most important advance has been in self-treatment devices. Hoffman $(112,113)$ found that burlap sacks treated with 5 per cent of a chlorinated hydrocarbon insecticide in oil and wrapped around a post or cable suspended between two posts provided effective control on cattle in feed lots. The effectiveness of such devices depends upon the extent to which cattle rub against them but is less than that obtained by thorough spraying or dipping.

Smith \& Richards (114) evaluated several new insecticides against lice on cattle, sheep, and goats when applied as sprays and dips. Strobane and toxaphene at 0.5 per cent concentration were about as effective as DDT against Haematopinus eurysternus (Nitzsch) on cattle. Of the organic phosphorus insecticides, malathion at 0.5 per cent, Bayer $21 / 199$ at 0.2 per cent, and Diazinon at 0.1 per cent gave perfect initial kill of lice and prevented reinfestation for two weeks. Parathion at 0.01 per cent and Am. Cyanamid 4124 at 0.25 per cent gave protection for three weeks. These insecticides were also highly effective against Bovicola caprae (Gurlt) and Bovicola limbatus (Gervais) on goats.

\section{Systemic InSECTICIDES}

One of the important trends in research on control of livestock insects during the last few years has been the increased emphasis on finding insecticides that can be fed or injected into the animals for destroying lice, ticks, cattle grubs, and biting flies. Many investigators have expressed doubt that it would ever be possible to find materials that would act systemically and destroy pests of livestock without seriously damaging the host. The idea does not seem unreasonable, however, because of progress made in control of various infections and parasites by internal medication. The antibiotics, for example, are highly effective against several human and animal diseases. It seems logical to expect success, and progress during recent years confirms the fact that insects feeding externally or internally, such as the cattle grub, can be destroyed by internal medication. However, the problem 
of developing an effective and safe material is not easy and entails an immense amount of careful research.

Systemic insecticides for livestock would have value in the control of several kinds of insects, especially cattle grubs. The only effective insecticide now in use is rotenone, which is sprayed on the backs. This method of control has serious limitations. At least two or three thorough sprayings are necessary during the coldest months of the year, and they must be applied when the grubs are in the back after they have already caused considerable damage. A single, effective treatment given when the grubs are still in the body of cattle would provide more practical and very likely less costly control. A similar treatment for the control of lice of cattle, sheep, and goats might also be practical.

Systemic insecticides for control of biting flies probably would not be practical for ordinary use, unless the material remained effective for several days. There are situations, however, where a systemic material of short duration would be useful. For example, in disease outbreaks the treatment of livestock every few days might break the chain of transmission by insects. The problem of finding a safe insecticide that will be retained by the animal and continue to kill bloodsucking insects such as flies for a week or two is indeed formidable, especially when excessive insecticide residues in meat and milk must be resolved.

The idea of internal use of insecticides for control of insect pests of animals is not new. Entomologists and others have considered this type of treatment for 30 years or more. During the 1920's numerous proprietary products flooded the market. These products were purported to control insects and related forms on animals, particularly poultry, when added to the feed. Parman et al. (115) reported work with dozens of chemicals against natural infestations of chicken lice and the fowl tick but concluded that none of them would control external parasites. Emmel (116) and Creighton et al. (117) found internal treatment with sulfur ineffective, although its presence in feed appeared to reduce louse infestations through external contamination of the animal. Although the early workers failed to find promising materials for systemic use, recent research has unearthed leads, and it is expected that practical systemic insecticides will be developed in the future.

Lindquist et al. (118) found that pyrethrum and DDT fed to rabbits in the laboratory had some systemic effect on bed bugs and mosquitoes. De Meillon (119) showed some activity of the-gamma isomer of BHC against the bed bug, yellow fever mosquito, and ticks when given to rabbits. Similarly, Garnham (120) showed that the gamma isomer of BHC given orally killed the yellow fever mosquito feeding on the rabbit. Knipling et al. (121), in testing 33 chemicals on rabbits, found some of the indandione compounds effective in killing the human body louse feeding on rabbits, and also confirmed the effectiveness of gamma BHC against mosquitoes. Adkins et al. (122) reported on the testing of 13 chemicals administered orally to rabbits for the control of bed bugs, Cimex lectularius Linnaeus, and the lone-star 
tick, Amblyomma americanum (Linnaeus). Bayer L 13/59, Bayer 18/178 (0-[2-(ethyl mercapto)methyl]-0,0-dimethyl thiophosphate), and Bayer 21/116 (0-[-2(ethyl mercapto)ethyl]-0,0-dimethyl thiophosphate) caused 100 per cent mortality of bed bugs and ticks feeding on rabbits treated at a rate of 200,130 , and $95 \mathrm{mg} . / \mathrm{kg}$. of body weight.

DeToledo \& Saur (123) reported that BHC given to cattle showed systemic effect against the human bot fly, Dermatobia hominis. Lindquist et al. (124) reported that dieldrin, aldrin, lindane, and heptachlor injected subcutaneously in mice caused mortality of the deer fly, C. discalis, and Aedes dorsalis (Meigen) mosquitoes taking blood meals, but when injected into cattle, they gave poor kills of natural populations of tabanids and mosquitoes feeding on the cattle. Roth \& Johnson (125) obtained high kills of grubs in experimental work when dieldrin was injected subcutaneously twice at the rate of $25 \mathrm{mg}$. $/ \mathrm{kg}$. of body weight. McGregor \& Radeleff (126) and McGregor et al. (127) reported good destruction of grubs with dieldrin, aldrin, and lindane. However, these chlorinated hydrocarbon insecticides are not considered satisfactory because large amounts are stored in the fat. Furthermore, the materials did not destroy young grubs in the bodies of the cattle. The same authors also tested organic phosphorus insecticides against the cattle grub. Although some of them showed promise, they did not measure up to the standards of effectiveness and safety required of systemic materials.

Schwartz et al. (128) reported on the free-choice ingestion of phenothiazine by cattle on the incidence of Hypoderma lineatum de Villers. The evidence suggests that the compound had some effect on larvae in the body of the host. However, observations on cattle herds consuming phenothiazine as routinely used for controlling internal parasites and the results of controlled experiments which are not yet reported in literature cast doubt on the effectiveness of phenothiazine as a grub-control medication.

The papers reviewed on systemic insecticides do not present critical and direct comparative data on their effect on insects in different host animals. Because of differences in assimilation or excretion, or the formation of metabolites of insecticides by different species of animals, there are dangers of overlooking valuable leads or misinterpreting the information obtained. The insects themselves are likely to differ in susceptibility or resistance to any given compound in different hosts. Future research will no doubt provide basic data that will explain apparent inconsistencies in older work and guide the research worker in developing effective systemic insecticides.

\section{Screw-worm Control with Sexually Sterile Males}

The eradication of the screw-worm, Callitroga hominivorax (Coquerel), from the island of Curacao, Netherlands Antilles, by the systematic weekly release of males sexually sterilized by gamma rays, reported by Baumhover et al. (129), was one of the most interesting events in recent entomological history. The fact that an insect was completely eliminated from an area, even of only 170 square miles, is of great importance. Of special interest, however, is the unique method of achieving the eradication. 
Sterile males were released at the rate of about 400 per square mile per week over a period of several months. The natural production of male screw-worm flies probably equaled 100 to 200 per square mile per week. The sterile males caused a rapid decline in production of flies, which meant that the ratio of sterile to fertile males increased rapidly. The natural screwworm population decreased enormously in about three months and complete eradication was achieved in five months.

The possibilities of this approach to control of the insect were indicated when Bushland \& Hopkins $(130,131)$ found in laboratory studies that $\mathrm{x}$-rays and gamma rays effectively sterilized the screw-worm. The maximum sterilizing effect with minimum adverse effect on adults was achieved by irradiating pupae. The optimum time was determined to be five to six days after pupation at $80^{\circ} \mathrm{F}$. or two or three days before adult emergence. A dose of 2,500 roentgens caused sterility of the males and 5,000 roentgens sterility of the females. These doses of irradiation do not adversely affect sexual behavior. In cage tests under laboratory conditions a given ratio of sterile to fertile males with a population of normal virgin females resulted in a like ratio of sterile to fertile egg masses. The findings of these authors were important milestones in screw-worm sterilization research and led to the field studies described previously.

The gamma-ray source used in the screw-worm experiments was described by Darden et al. (132). This portable unit meets the requirements of maximum irradiation chamber size and amounts of cobalt 60 at reasonable cost without violating accepted radioactive safety standards.

The feasibility of controlling the screw-worm by releasing sexually sterile males was suggested by information obtained over many years by a number of investigators on the life history, ecology, population densities, host relationships, and other aspects of screw-worm biology. Some of the significant observations having a bearing on this problem have been reviewed by Lindquist (133).

Theoretical considerations in the use of the sterilization method for insect control are discussed by Knipling (134). The principle of reducing the population of an insect by sustained release of sterile males among an existing population is a mathematical proposition. If the first release of an insect exceeds the native population by five or ten times, the next generation should be greatly reduced provided the population is stable. Sustained releases in the same numbers originally released will naturally provide for a higher and higher ratio of sterile to fertile insects. In several generations, therefore, the extinction point of the species should be reached. The Curacao experiment bore out the calculated decimation of the screw-worm population to an amazing degree.

On the basis of information available at the present time, the sterilization method will be feasible for relatively few insects. Several definite requirements must be considered in appraising the possibilities of controlling or eradicating an insect. (a) An economical method of rearing millions of insects must be known or capable of development. (b) The insect must be of a 
type that can readily be dispersed so that released males can successfully compete with native males for virgin females. (c) The sterilizing method must produce sterility without serious adverse effects on the insect. (d) The females should preferably mate only once, but if multiple matings occur, the irradiated (sterile) males must produce sperm so as to compete with sperm of the native fertile males. $(e)$ The insect to be controlled must have a low population or must be reduced by other methods. The area to be treated must, of course, be reasonably protected against reinfestation. In estimating the possibilities for use of sterilization for control, the above factors should be taken into consideration. Obviously, a thorough knowledge of the habits and ecology of the insect must be available.

\section{RADIOISOTOPES IN RESEARCH}

Since 1949 the use of radioisotopes in research on arthropods of medical and veterinary importance has increased greatly. One of the important uses of radioisotopes is in ecological studies. Insects can easily be tagged with these materials and upon later recapture, they can be positively identified with Geiger counters. The tagging procedure can be used in studies on flight, movement or migration in or on the soil, in foods, feeds, and animals. Studies on systemic insecticides in animals can be greatly aided by labeled materials. The uptake of blood, serum, or tissues by insects and determinations of the amount and possible identity of metabolites can be speeded with labeled insecticides. Insect populations in a locality can be determined from ratios of tagged to untagged specimens. The same method can be used to measure the effectiveness of control operations.

Several writers, including Bugher \& Taylor (135), Jenkins \& Hassett (136), Thurman \& Husbands (137), and Provost (138), have reported on experiments with mosquitoes to determine flight range, direction of flight, age, and estimated population densities. In most of these experiments the mosquitoes were tagged with $\mathrm{P}^{\mathbf{8 2}}$. Similar studies on house flies and blow flies have been made by Yates et al. (139), Schoof et al. (140), and Quarterman et al. (141). General review papers on the uses of radioisotopes in insect research include those by Jenkins \& Hassett (142), Jenkins (143), and Lindquist (144).

Radioactive insecticides are useful in studies of the absorption, distribution, and degradation of the materials when applied in measured dosages to insects. Several insecticides including DDT, BHC, parathion, pyrethrins, allethrin, and methyl bromide have been labeled with radioisotopes [Dahm (145)]. This author reviews methods of labeling various chemicals and uses which have been made of them.

\section{LITERATURE CITED}

1. Whitnall, A. B. M., Thorburn, J. A., McHardy, W. M., Whitehead, G. B., and Meerholz, F., Bull. Entomol. Research, 43, 51 (1952)

2. Fiedler, O. G. H., Onderstepoort J. Vet. Research, 25, 65 (1952)

3. Hitchoock, L. F., Australian J. Agr. Research, 4, 360 (1953) 
4. Hoskins, W. M., and Gordon, H. T., Ann. Rev. Entomol., 1, 89 (1955)

5. Fuller, H. S., Ann. Rev. Entomol., 1, 347 (1955)

6. Lindsay, D. R., and Scudder, H. I., Ann. Rev. Entomol., 1, 323 (1955)

7. Buxton, P. A., Memoirs London School Hyg. Tropical Med., p. 10 (H. K. Lewis \& Co., Ltd., London, England, 816 pp., 1955)

8. du Toit, R., Onderstepoort J. Vet. Research, 26, 317 (1954)

9. Nash, T. A. M., and Page, W. A., Trans. Roy. Entomol. Soc. (London), 104, 71 (1953)

10. Jackson, C. H. N., J. Animal Ecol., 22, 78 (1953)

11. Glasgow, J. P., and Wilson, F., J. Animal Ecol., 22, 47 (1953)

12. Nash, T. A. M., Bull. Entomol. Research, 46, 357 (1955)

13. Glover, P. E., Jackson, C. H. N., Robertson, A. G., and Thomson, W. E. E., Bull. Entomol. Research, 46, 57 (1955)

14. Fiedler, O. G. H., du Toit, R., and Kluge, E. B., Onderstepoort J. Vet. Research, 26, 389 (1954)

15. Burnett, G. F., Bull. Entomol. Research, 45, 411 (1954)

16. Hocking, K. S., Yeo, D., and Anstey, D. G., Bull. Entomol. Research, 45, 585 (1954)

17. Hocking, K. S., Burnett, G. F., and Sell, R. C., Bull. Entomol. Research, 45, 605 (1954)

18. Hocking, K. S., Burnett, G. F., and Sell, R. C., Bull. Entomol. Research, 45, 613 (1954)

19. Oldroyd, H., The Horse Fies (Diptera: Tabanidae) of the Ethiopian Region, Vol. 2, Tabanus and Related Genera (British Museum Natural History, London, England, 341 pp., 1954)

20. Philip, C. B., Rev. brasil. entomol., 2, 13 (1954)

21. Philip, C. B., Rev. brasil. entomol., 3, 47 (1955)

22. Mackerras, I. M., Australian J. Zool., 2, 431 (1954)

23. Mackerras, I. M., Australian J. Zool., 3, 439 (1955)

24. Basu, B. C., Balarama Menon, P., and Sen Gupta, C. M., Indian J. Vet. Sci., 22, 273 (1953)

25. Crewe, W., Ann. Trop. Med. Parasitol., 47, 340 (1953)

26. Fairchild, G. B., Proc. Entomol. Soc. Wash., 55, 239 (1953)

27. Lumsden, A. J., Bull. Entomol. Research, 42, 721 (1952)

28. Duke, B. O. L., Ann. Trop. Med. Parasitol., 49, 193 (1955)

29. Jones, C. M., J. Econ. Entomol., 46, 1108 (1953)

30. Lewis, L. F., and Jones, C. M., J. Econ. Entomol., 48, 609 (1955)

31. Blickle, R. L., Psyche, 61, 74 (1954)

32. Fairchild, G. B., Conr. State Geol. and Nat. Hist. Survey Bull., 75, 3 (1950)

33. Knutson, H., Coker, E. I., Lisciotto, F. R., and Kuschke, J. C., Mosquito Newes, 14, 205 (1954)

34. Brown, A. W. A., and Mortison, P. E., J. Econ. Entomol., 48, 125 (1955)

35. Roth, A. R., J. Econ. Entomol., 47, 361 (1954)

36. Roth, A. R., Mote, D. C., and Lindquist, D. A., ARS-33-2 (U. S. Agricultural Research Service, 10 pp., 1954)

37. Goodwin, W. J., Moore, S., 3rd, and Schwardt, H. H., J. Econ. Entomol., 46, 1088 (1953)

38. Bruce, W. N., and Decker, G. C., J. Econ. Entomol., 44, 154 (1951)

39. Bruce, W. N., and Decker, G. C., J. Econ. Entomol., 48, 167 (1955)

40. Bruce, W. N., Biological Notes 27 (Natural History Survey Division, State of Illinois, Urbana, Ill., 11 pp., 1952) 
41. Ferris, D. H., Hanson, R. P., Dicke, R. J., and Roberts, R. H., J. Infectious Diseases, 96, 184 (1955)

42. Day, M. F., and Bennetts, M. J., A Review of Problems of Specificity in Arthropod Vectors of Plant and Animal Viruses (Commonwealth Scientific and Industrial Research Organization, Canberra, Australia, 172 pp., 1954)

43. Champlain, R. A., Fisk, F. W., and Dowdy, A. C., J. Econ. Entomol., 47, 940 (1954)

44. McGregor, W. S., and Dreiss, J. M., J. Econ. Entomol., 48, 327 (1955)

45. Moore, D. H., Dove, W. E., and Dickenson, B. C., Agr. Chemicals, 9, 31 (1954)

46. Dahm, P. M., and Raun, E. S., J. Econ. Entomol., 48, 317 (1955)

47. Bruce, W. N., and Decker, G. C., J. Econ. Entomol., 40, 530 (1947)

48. Laake, E. W., J. Econ. Entomol., 39, 65 (1946)

49. Rogoff, W. M., S. Dakota Agr. Expt. Sta. Bull., No. 418 (1952)

50. Rogoff, W. M., and Moxon, A. L., J. Econ. Entomol., 45, 329 (1952)

51. Lindquist, A. W., and Hoffman, R. A., J. Econ. Entomol., 47, 79 (1954)

52. Foote, R. H. F., and Pratt, H. D. P., U. S. Pub. Health Monograph, 18, 53 pp. (1954)

53. Khalaf, K., Ann. Entomol. Soc. Amer., 47, 34 (1954)

54. Vargas, L., and Wirth, W. W., Mexican Inst. Salubridad Enferm. Trop. Rev., 15, 33 (1955)

55. Vargas, L., Mexican Inst. Salubridad Enferm. Trop. Rev., 14, 25 (1954)

56. Kettle, D. S., and Lawson, J. W. H., Proc. Roy. Entomol. Soc. (London), [B]24, 37 (1955)

57. Forattini, O. P., Rev. brasil. Entomol., 1, 136 (1954)

58. Ortiz, I., and Leon, L. A., Bull. Inform. Cient. Nac., 7, 564 (1955)

59. Wirth, W. W., Proc. Entomol. Soc. Wash., 57, 109 (1955)

60. Williams, R. W., Ann. Entomol. Soc. Amer., 48, 30 (1955)

61. Blanton, F. S., Graham, O. H., and Keenan, C. M., Mosquito News, 15, 13 (1955)

62. Woke, P. A., Ann. Entomol. Soc. A mer., 47, 61 (1954)

63. Okada, T., Oyo-Dobutsug.-Zasshi., 19, 1 (1954)

64. Downes, J. A., Trans. Roy. Entomol. Soc. (London), 106, 213 (1955)

65. Hardy, W. T., and Price, D. A., J. Am. Vet. Med. Assoc., 120, 23 (1952)

66. Price, D. A., and Hardy, W. T., J. Am. Vet. Med. Assoc., 124, 255 (1954)

67. Riek, R. F., Australian J. Agr. Research, 5, 109 (1954)

68. Labrecque, G. C., and Goulding, R. L., Mosquito News, 14, 20 (1954)

69. Bentinck, W. C., The Black Flies of Japan and Rorea (U. S. Army 406th Med. General Lab., Tokyo, Japan, APO 500, 23 pp., 1955)

70. Freeman, P., and De Meillon, B., Simuliidae of the Ethiopian Region (British Museum Natural History, London, England, 224 pp., 1953)

71. Stone, A. S., and Jamnback, H. A., N. Y. State Museum Bull. No. 349 (1955)

72. Sommerman, K. M., Sailer, R. I., and Esselbaugh, C. O., Ecol. Monographs, 25, 345 (1955)

73. Sailer, R. I., Mosquito News, 13, 232 (1953)

74. Bierer, B. W., Vet. Med., 49, 107 (1954)

75. Curtis, L. C., Proc. Entomol. Soc. Brit. Columbia, 51, 3 (1954)

76. Edgar, S. A., Poultry Sci., 32, 279 (1954)

77. Dalmat, H. T., Smithsonion Misc. Collection, 125, No. 1, 425 pp. (1955)

78. Hocking, B., and Pickering, L. R., Can. J. Zool., 32, 99 (1954)

79. Edmunds, L. R., Mosquito News, 14, 65 (1954)

80. Jones, C. M., and Richey, D. J., J. Econ. Entomol., 49, 121 (1956) 
81. Simms, B. T., Report of Chief of Bureau of Animal Industry, U. S. Dept. Agr., p. 83 (1953)

82. Richey, D. J., and Ware, R. E., Cornell Vet., 45, 642 (1954)

83. Newberne, J. W., Am. J. Vet. Research, 16, 593 (1954)

84. Fairchild, G. B., and Barreda, E. A., J. Econ. Entomol, 38, 694 (1945)

85. Gjullin, C. M., Cope, O. B., Quisenberry, B. F., and DuChanois, F. R., J. Econ. Entomol., 42, 100 (1949)

86. Hocking, B., Sci. Agr., 30, 489 (1950)

87. Vargas, L., Mexican Inst. Salubridad Enferm. Trop. Rev., 9, 313 (1948)

88. Lea, A. O., and Dalmat, H., J. Econ. Entomol., 48, 274 (1955)

89. Garnham, P. C. C., Bull. Entomol. Research, 45, 175 (1954)

90. Hocking, B., and Richards, W. R., Bull. Entomol. Research, 43, 237 (1952)

91. Lea, A. O., and Dalmat, H. T., J. Econ. Entomol., 48, 378 (1955)

92. Lea, A. O., and Dalmat, H. T., J. Econ. Entomol., 47, 135 (1954)

93. Jamnback, H., and Collins, D. L., N. Y. State Museum Bull. No. 350 (1955)

94. Laake, E. W., J. Econ. Entomol., 46, 454 (1953)

95. Neel, W. W., J. Econ. Entomol., 47, 540 (1954)

96. Adams, P. G., Castillo, C. H., and Salmeron, R., Agr. Chemicals, 7, 33 (1953)

97. Garr, E. I., Velerinariya, 31, 47 (1954)

98. Breev, K. A., and Karazeeva, Z. F., Parasit. Sborn., 15, 410 (1953)

99. Breev, K. A., and Savel'ev, D. V., Velerinariya, 31, 35 (1954)

100. Smith, C. L., and Richards, R., J. Econ. Entomol., 47, 712 (1954)

101. Roth, A. R., and Eddy, G. W., J. Econ. Entomol., 48, 201 (1955)

102. Kühl, R., Anz. Schädlingskunde, 27, 7 (1954)

103. Raun, E. S., J. Econ. Entomol., 48, 603 (1955)

104. Lienert, E., and Thorsell, W., Expll. Parasitol., 4, 117 (1955)

105. Waterhouse, D. F., and Paramonov, S. J., Australian J. Sci., 3, 310 (1950)

106. Waterhouse, D. F., and Scott, M. T., Australian J. Agr. Research, 1, 440 (1950)

107. Riches, J. H., and O'Sullivan, P. J., Australian Vet. J., 31, 258 (1955)

108. Peterson, H. O., Roberts, I. H., Becklund, W. W., and Kemper, H. E., J. Am. Vet. Med. Assoc., 122, 373 (1953)

109. Knipling, E. F., Insects. The Yearbook of Agr., p. 662 (U. S. Government Printing Office, Washington, D. C., 780 pp., 1952)

110. U. S. Dept. Agr., Leaflet No. 308 (1951)

111. U. S. Dept. Agr., Leaflet No. 319 (1951)

112. Hoffman, R. A., J. Econ. Entomol., 47, 701 (1954)

113. Hoffman, R. A., J. Econ. Entomol., 47, 1152 (1954)

114. Smith, C. L., and Richards, R., J. Econ. Entomol., 48, 566 (1955)

115. Parman, D. C., Abbot, W. S., Culver, J. J., and Davidson, W. M., U. S. Dept. Agr. Technical Bull., 60, 1 (1928)

116. Emmel, M. W., Florida Agr. Expl. Sta. Bull., 374 (1942)

117. Creighton, J. T., Dekle, G. W., and Russell, J., J. Econ. Entomol., 36, 413 (1943)

118. Lindquist, A. W., Knipling, E. F., Jones, H. A., and Madden, A. H., J. Econ. Entomol., 37, 128 (1944)

119. De Meillon, B., Nature, 158, 839 (1946)

120. Garnham, P. C. C., Nature, 160, 156 (1947)

121. Knipling, E. F., Bushland, R. C., Babers, F. H., Culpepper, G. H., and Raun, E. S., J. Parasitol., 34, 55 (1948)

122. Adkins, R. A., Jr., Sowell, W. L., and Arant, F. S., J. Econ. Entomol., 48, 139 (1955) 
123. deToledo, A. A., and Saur, H. F. G., Biologica, 16, 25 (1950)

124. Lindquist, A. W., Roth, A. R., Hoffman, R. A., and Yates, W. W., J. Econ. Entomol., 46, 610 (1953)

125. Roth, A. R., and Johnson, J. B., J. Econ. Entomol., 48, 761 (1955)

126. McGregor, W. S., and Radeleff, R. D., J. Econ. Entomol., 47, 465 (1954)

127. McGregor, W. S., Radeleff, R. D., Claborn, H. V., and Bushland, R. C., Agr. Chemicals, 10, 34 (1955)

128. Schwartz, B., Porter, D. A., and Herlich, H., Vet. Med., 49, 405 (1954)

129. Baumhover, A. H., Graham, A. J., Bitter, B. A., Hopkins, D. E., New W. D., Dudley, F. H., and Bushland, R. C., J. Econ. Entomol., 48, 462 (1955)

130. Bushland, R. C., and Hopkins, D. E., J. Econ. Entomol., 44, 725 (1951)

131. Bushland, R. C., and Hopkins, D. E., J. Econ. Entomol., 46, 648 (1953)

132. Darden, E. B., Jr., Maeyens, E., and Bushland, R. C., Nucleonics, 12, 60 (1954)

133. Lindquist, A. W., J. Econ. Entomol., 48, 467 (1955)

134. Knipling, E. F., J. Econ. Entomol., 48, 459 (1955)

135. Bugher, J. C., and Taylor, M., Science, 110, 146 (1949)

136. Jenkins, D. W., and Hassett, C. C., Can. J. Zool., 29, 178 (1951)

137. Thurman, D. C., Jr., and Husbands, R. C., Communicable Disease Center Bull. (U. S. Public Health Service), 10, 1 (1951)

138. Provost, M. W., Mosquito News, 12, 174 (1952)

139. Yates, W. W., Lindquist, A. W., and Butts, J. S., J. Econ. Entomol., 45, 547 (1952)

140. Schoof, H. F., Siverly, R. E., and Jensen, J. A., J. Econ. Entomol., 45, 675 (1952)

141. Quarterman, K. D., Mathis, W., and Kilpatrick, J. W., J. Econ. Entomol., 47, 405 (1954)

142. Jenkins, D. W., and Hassett, C. C., Nucleonics, 6, 5 (1950)

143. Jenkins, D. W., Exptl. Parasitol., 3, 474 (1954)

144. Lindquist, A. W., J. Econ. Entomol., 45, 264 (1952)

145. Dahm, P. A., Soap Sanit. Chemicals. 29. 141 (1953) 